\title{
Hubungan Karakteristik Inovasi dan Kearifan Lokal terhadap Keberlanjutan Penerapan Teknologi Padi Salibu di Kabupaten Tanah Datar, Sumatera Barat
}

\author{
Effect of Innovation and Local Wisdom on Sustainability of Salibu Rice \\ in Tanah Datar Regency, West Sumatera
}

\author{
Sri Wahyuni ${ }^{1}$, Zulvera ${ }^{1}$, Heri Bachrizal Tanjung ${ }^{1}$, Ernita Arif ${ }^{2}$ \\ ${ }^{1}$ Fakultas Pertanian Universitas Andalas, Padang \\ ${ }^{2}$ Fakultas Ilmu Sosial dan Politik Universitas Andalas, Padang
}

\begin{abstract}
Salibu rice is a product of a local wisdom in technology in West Sumatera to help widows and poor families. The sustainability of rice cultivation depends on the characteristics of farmers, innovation, and farmers'perception of local wisdom. This study was aimed to (1) describe the sustainability of salibu technology in Tanah Datar, and (2) assess the effect of rice innovation and local wisdom on the sustainability of Salibu technology in Tanah Datar. This study is of a quantitative design with a survey method and supported by qualitative data. The study sites were purposively selected based on the topographical aspects: Sungai Tarab representing lowland and Batipuh representing the plateau. The results showed that the sustainability of Salibu rice technology in Sungai Tarab and Batipuh is well supported by innovation characteristics and local wisdom - farmers in both sub-districts apply the Salibu rice technology in each planting season. In Sungai Tarab, sustainability is related to the characteristics of innovation (relative benefits, suitability, complexity of innovation, ease, and observability of innovation) and local wisdom (knowledge, skills, and social processes). In Batipuh, sustainability is related to the characteristics of innovation (suitability, complexity of innovation, and ease) and local wisdom (social processes).
\end{abstract}

Keywords: Innovation, local wisdom, sustainability, salibu rice

\begin{abstract}
Abstrak
Padi Salibu merupakan kearifan lokal dalam teknologi padi di Sumatera Barat yang menerapkan prinsip gotong royong dan kebersamaan serta tolong menolong terutama untuk membantu janda dan orang miskin. Teknologi Padi Salibu kembali dikembangkan di Sumatera Barat berkat perhatian peneliti dari BPTP Solok, dan telah diakui oleh Kemeterian Pertanian sebagai salah satu inovasi dalam teknologi padi. Keberlanjutan penerapan Padi Salibu sangat ditentukan oleh karakteristik petani, karakteristik inovasi, dan persepsi petani terhadap kearifan lokal. Penelitian ini bertujuan untuk: (1) mendeskripsikan tingkat keberlanjutan penerapan Padi Salibu di Kabupaten Tanah Datar, dan (2) menganalisis hubungan karakteristik inovasi Padi Salibu dan kearifan lokal dengan tingkat keberlanjutan penerapan Padi Salibu di Kabupaten Tanah Datar. Penelitian ini dirancang secara kuantitatif menggunakan metode survei dan didukung oleh data kualitatif. Lokasi penelitian dipilih secara purposif berdasarkan topografi lokasi, yaitu Kecamatan Sungai Tarab mewakili dataran rendah dan Kecamatan Batipuh mewakili dataran tinggi. Hasil penelitian menunjukkan bahwa tingkat keberlanjutan penerapan teknologi Padi Salibu di kecamatan Sungai Tarab dan Kecamatan Batipuh sudah baik didukung oleh karakteristik inovasi dan kearifan lokal, di mana petani di kedua kecamatan telah menerapkan teknologi Padi Salibu pada setiap musim tanam. Di Kecamatan Sungai Tarab, keberlanjutan berhubungan dengan karakteristik inovasi yang terdiri atas keuntungan relatif, tingkat kesesuaian, tingkat kerumitan inovasi, tingkat kemudahan, dan tingkat keteramatan inovasi; dan kearifan lokal yang terdiri atas pengetahuan lokal, keterampilan lokal, dan proses sosial lokal. Di Kecamatan Batipuh, keberlanjutan berhubungan dengan karakteristik inovasi yang terdiri atas tingkat kesesuaian, tingkat kerumitan inovasi, dan tingkat kemudahan; dan kearifan lokal yaitu proses sosial lokal.
\end{abstract}

Kata kunci: inovasi, kearifan lokal, keberlanjutan, Padi Salibu

\section{Pendahuluan}

Sumatera Barat merupakan salah satu propinsi yang mempunyai banyak kearifan lokal (indigenous knowledge), salah satunya adalah Padi Salibu. Istilah tanaman padi berasal dari tunas yang tumbuh dari tunggul batang yang telah dipanen dan menghasilkan anakan baru hingga dapat dipanen kembali (Balitbangtan, 2015). Balai Pengkajian Teknologi Padi Salibu lebih dikenal dengan padi ratun, yaitu

Pertanian (BPTP) Sukarami Kabupaten Solok pada tahun 2013 mengembangkan teknologi Padi Salibu yang menitikberatkan pada teknologi pemotongan di mana padi sebaiknya dipotong sebelum berumur seratus hari, idealnya sepuluh hari sebelum panen. Hal ini dimaksudkan untuk pertumbuhan anakan baru sehingga pertumbuhan anakan menjadi maksimal (Balitbangtan, 2015). Teknologi Padi Salibu yang dikembangkan BPTP Solok telah diakui oleh Kementerian Pertanian sebagai salah satu teknologi tanaman pangan. Pada tahun 2015

${ }^{1}$ Korespondensi penulis 
pemerintah menargetkan pencapaian swasembada dapat dicapai dalam tiga tahun ke depan, dengan pertumbuhan $2,21 \%$ per tahun.

Teknologi budidaya Padi Salibu merupakan salah satu upaya untuk mencapai target tersebut, selain Sumatera Barat Padi Salibu juga telah dicoba di beberapa daerah lain seperti Jawa Timur, Kalimantan Selatan, Kalimantan Utara, Sulawesi Tengah, Sumatra Selatan, Riau, Aceh, Sumut, Babel, NTB dan lain-lain (Balitbangtan, 2015). Luas lahan di Indonesia yang digunakan untuk penerapan Padi Salibu hingga tahun 2017 sebesar 10.000 hektar. Daerah yang menerapkan Padi Salibu adalah Sumatera Barat sebanyak 2.000 hektar, Jawa Barat 2.000 hektar, Jawa Tengah 2.000 hektar, Jawa Timur 2.000 hektar, Sulawesi Selatan 1.000 hektar dan Bali 1.000 hektar (Dirjen Tanaman Pangan, 2017).

Beberapa keuntungan yang dapat diperoleh dari penerapan teknologi Padi Salibu adalah: hemat tenaga kerja, waktu, dan biaya, karena tidak dilakukan pengolahan tanah dan penanaman ulang, selain itu menekan kebiasaan petani membakar jerami setelah panen (Erdiman et al., 2013). Teknologi Padi Salibu dapat meningkatkan meningkatkan indek panen/IP (jumlah panen dalam setahun) karena waktu produksi menjadi lebih pendek, hanya membutuhkan 80-90\% waktu dibandingkan tanaman pertamanya. Hal ini akan meningkatkan IP berkisar 0,5 s/d 1 /tahun, meningkatkan produktivitas tiga hingga enam ton gabah/ha/tahun setara Rp 12 juta s/d 24 juta/ha/ tahun. Jika dibandingkan dengan teknologi ratun konvensional, teknologi Padi Salibu mampu menghasilkan jumlah anakan yang lebih banyak dan seragam, dan produktivitas bisa sama bahkan lebih tinggi dari tanaman utamanya (Erdiman, 2013).

Penerapan teknologi Padi Salibu akan lebih menggairahkan aktivitas usahatani, karena dapat diperoleh tambahan hasil yang sangat nyata Penelitian Erdiman (2013) menjelaskan bahwa terdapat berbagai keuntungan teknologi Padi Salibu, di antaranya adalah Selain itu, secara ekonomis teknologi Padi Salibu menghemat biaya $60 \%$ untuk pekerjaan persiapan lahan dan menanam, 30\% untuk biaya produksi, hal ini menekan biaya setara Rp. 2 juta s/d 3 juta/ha dalam satu kali panen. Budidaya Padi Salibu akan lebih ekonomis sekitar $45 \%$ dibanding budidaya tanam pindah, hal inilah yang meningkatkan pendapatan petani (Erdiman, 2013).
Keberlanjutan penerapan teknologi Padi Salibu di Sumatera Barat sebagai daerah sentral diketahui masih terfokus di Kabupaten Tanah Datar sehingga pengembangan Padi Salibu di daerah lain tidak optimal. Padahal, dengan berbagai keuntungan penerapan Padi Salibu tersebut seperti rendahnya biaya produksi dan meningkatnya jumlah panen dalam satu tahun, harusnya mampu mendorong tingginya tingkat adopsi Padi Salibu oleh petani-petani padi di Sumatera Barat, terutama karena teknologi Padi Salibu bersumber dari kearifan lokal masyarakat setempat. Akan tetapi, belum ada kajian ilmiah yang secara rinci membahas hal tersebut. Temuan terkait Padi Salibu atau padi ratun hingga saat ini berpusat pada budidaya dan sistem teknologi, seperti penelitian yang dilakukan oleh Suwandi et al. (2012) bahwa ekstrak kompos dapat meningkatkan hasil dan menekan penyakit padi sistem ratun di sawah pasang surut kabupaten Banyuasin; hasil penelitian Susilawati dan Purwoko (2012) menyebutkan bahwa pemupukan ratun setengah dari dosis pada tanaman utama dapat meningkatkan gabah per malai dan bahwa usahatani dengan sistem ratun sangat layak diusahakan di lahan pasang surut.

hasil temuan Erdiman et al. (2013) bahwa penggunaan varietas padi Batang Piaman memberikan hasil lebih dari 6 ton/hektar (peningkatan 10\%-15\%) sehingga teknologi Padi Salibu dapat dikembangkan dengan menggunakan varietas padi tersebut; hasil penelitian oleh Erdiman (2013) yang menyatakan bahwa teknologi Padi Salibu meningkatkan jumlah panen karena tidak melakukan pengolahan tanah dan persemaian dan tanam sehingga rentang waktu produksi lebih pendek, serta dapat menanggulangi keterbatasan varietas unggul; hasil temuan Ritonga (2015) yang menyebutkan bahwa interaksi galur ratun dengan lingkungan berpengaruh sangat nyata terhadap jumlah anakan produktif, serta dapat beradaptasi di Kabupaten Pelalawan.

temuan Sinaga et al. (2015) bahwa tanaman ratun sensitif terhadap lingkungan dan bahwa tanaman ratun meningkatkan hasil padi di lahan pasang surut; penelitian Dewi et al. (2015) yang menemukan bahwa aplikasi bioinsektisida B.bassiana memengaruhi kelimpahan dan kekayaan spesies laba-laba di ekosistem padi ratun; dan hasil penelitian Herlinda et al. (2015) mengenai perbandingan efek pemberian bioinsektisida dan ekstrak kompos terhadap produksi ratun dan populasi serangga hama. 
Berbeda dengan penelitian sebelumnya yang mengkaji aspek budidaya Padi Salibu, penelitian ini akan terfokus untuk melihat keberlanjutan penerapan padi salibu terutama ditinjau dari aspek karakteristik inovasi padi salibu dan kearifan lokal padi salibu. Penelitian ini secara umum bertujuan menganalisa keberlanjutan penerapan teknologi Padi Salibu oleh petani. Secara khusus, tujuan penelitian ini adalah: (1) mendeskripsikan tingkat keberlanjutan penerapan teknologi Padi Salibu di Kabupaten Tanah Datar, dan (2) menganalisa hubungan karakteristik inovasi Padi Salibu dan kearifan lokal dengan tingkat keberlanjutan penerapan teknologi Padi Salibu di Kabupaten Tanah Datar.

\section{Metode Penelitian}

Penelitian ini dirancang secara kuantitatif menggunakan metode survei dan didukung dengan data kualitatif. Terdapat empat daerah yang mengembangkan teknologi Padi Salibu di Sumatera Barat, yaitu Kabupaten Tanah Datar sebanyak 500 hektar, Kabupaten Lima Puluh Kota sebanyak 500 hektar, Kabupaten Agam sebanyak 500 hektar, dan Kabupaten Solok sebanyak 500 hektar (Dirjen Tanaman Pangan, 2017). Lokasi penelitian dipilih secara purposif, yaitu di Kabupaten Tanah Datar dengan mempertimbangkan bahwa Kabupaten Tanah Datar merupakan daerah percontohan yang mengembangkan teknologi Padi Salibu oleh BPTP Sukarami dan sampai saat ini hampir seluruh kecamatan di Kabupaten Datar masih mengembangkan teknologi Padi Salibu. Dua kecamatan terpilih yaitu Kecamatan Sungai Tarab diwakili oleh Kelompok tani Surau Jambu dan Kecamatan Batipuh diwakili oleh Kelompok Tani Beringin Bersatu. Penelitian ini dilaksanakan pada bulan Agustus hingga bulan Oktober 2017.

Populasi penelitian adalah petani yang telah menerapkan teknologi Padi Salibu di kecamatan terpilih di Kabupaten Tanah Datar. Pengambilan sampel dilakukan secara sensus, yaitu 48 orang di Kelompok Tani Surau Jambu Kecamatan Sungai Tarab dan 51 orang di Kelompok Tani Beringin Bersatu Kecamatan Batipuh. Jenis data yang dikumpulkan pada penelitian ini terdiri dari data primer yang diperoleh melalui wawancara menggunakan kuesioner dan data sekunder diperoleh dari Dinas Pertanian, Balai Penyuluhan Pertanian dan Badan Pusat Statistik. Analisis data penelitian dilakukan dengan menggunakan analisis statitistik deskriptif untuk medeskripsikan karakteristik inovasi teknologi Padi
Salibu, kearifan lokal, dan keberlanjutan penerapan Padi Salibu; dan uji statistik inferensia untuk menganalisa hubungan karakteristik inovasi teknologi Padi Salibu dan kearifan lokal dengan keberlanjutan penerapan Padi Salibu di Kabupaten Tanah Datar. Uji statistik inferensia menggunakan analisa korelasi rank Spearman. Selain itu, penelitian ini juga melakukan uji beda untuk melihat perbedaan keberlanjutan penerapan Padi Salibu di dua kelompok tani yang mewakili dua kecamatan terpilih. Uji statistik deskriptif dan uji statistis inferensia dilakukan dengan menggunakan software SPSS 23.00.

\section{Hasil dan Pembahasan}

\section{Keberlanjutan Penerapan Teknologi Padi Salibu}

Umumnya petani responden sudah berkelanjutan dalam menerapkan teknologi Padi Salibu, baik di Kecamatan Sungai Tarab maupun di Kecamatan Batipuh. Hal ini mengindikasikan bahwa petani di kedua kecamatan menerapkan teknologi Padi Salibu pada setiap musim tanam, menggunakan lahan untuk musim tanam berikutnya, serta adanya perluasan lahan yang ditanami Padi Salibu. Hasil tersebut dapat dilihat pada Tabel 1.

Hasil uji beda pada Tabel 1 memperlihatkan bahwa terdapat perbedaan nyata pada taraf signifikan 0,05 pada indikator keberlanjutan pertambahan luas lahan penerapan Padi Salibu antara kecamatan Sungai Tarab dan Kecamatan Batipuh. Akan tetapi, secara umum untuk indikator lainnya diketahui bahwa tidak terdapat perbedaan nyata pada taraf signifikan 0,05 antara keberlanjutan penerapan Padi Salibu di antara kedua kecamatan tersebut. Hal ini mengindikasikan bahwa secara umum petani responden di kedua kecamatan sudah menerapkan Padi Salibu secara berkelanjutan pada setiap musim tanamnya.

Hasil pengamatan di lapangan, keberlanjutan penerapan teknologi Padi Salibu oleh petani didorong oleh berbagai keuntungan, seperti hemat dari segi biaya, waktu dan tenaga kerja, serta dapat menambah jumlah produksi dan total panen dalam satu tahun, di mana hal tersebut sejalan dengan hasil penelitian Erdiman (2013). Selain itu, salah satu hal menarik di kecamatan Sungai Tarab adalah keberlanjutan penggunaan lahan untuk Padi Salibu diiringi dengan kegiatan mina padi, yaitu memasukkan ikan ke dalam lahan sawah petani, yang dinamakan oleh petani sebagai mina Padi Salibu. Hal tersebut menjadi 
Tabel 1. Keberlanjutan Penerapan Teknologi Padi Salibu di Kecamatan Sungai Tarab dan Kecamatan Batipuh Kabupaten Tanah Datar

\begin{tabular}{|c|c|c|c|c|c|}
\hline \multirow[b]{2}{*}{ No. } & \multirow[b]{2}{*}{ Kearifan Lokal } & \multicolumn{2}{|c|}{ Persentase $(\%)$} & \multirow{2}{*}{$\begin{array}{l}\text { Total } \\
(n=99)\end{array}$} & \multirow[b]{2}{*}{ Uji Beda } \\
\hline & & $\begin{array}{l}\text { Sungai Tarab } \\
\quad(n=48)\end{array}$ & $\begin{array}{c}\text { Batipuh } \\
(n=51)\end{array}$ & & \\
\hline \multirow[t]{2}{*}{1.} & Keberlanjutan Penerapan Padi Salibu setia & musim tanam & & & 0.391 \\
\hline & Rendah & 0 & 0 & 0 & 0,391 \\
\hline \multirow{4}{*}{2.} & Tinggi & 100,0 & 100,0 & 100,0 & \\
\hline & Keberlanjutan Penggunaan lahan & & & & \\
\hline & Rendah & 0 & 0 & 0 & 0,497 \\
\hline & Tinggi & 100,0 & 100,0 & 100,0 & \\
\hline \multirow[t]{3}{*}{3.} & Keberlanjutan Pertambahan luas lahan & & & & \\
\hline & Rendah & 0 & 49,0 & 25,3 & $0,000 * *$ \\
\hline & Tinggi & 100,0 & 51,0 & 74,7 & \\
\hline \multirow[t]{2}{*}{4.} & Keberlanjutan penerapan Padi Salibu & & & & \\
\hline & Rendah & 0 & 2,0 & 1,0 & 0,626 \\
\hline \multirow[t]{4}{*}{5.} & $\begin{array}{l}\text { Tinggi } \\
\text { Keberlanjutan Pengembangan Padi Salibu }\end{array}$ & 100,0 & 98,0 & 99,0 & \\
\hline & $\begin{array}{l}\text { Rendah } \\
\text { lat }\end{array}$ & 0 & 0 & 0 & 0,516 \\
\hline & Tinggi & 100,0 & 100,0 & 100,0 & \\
\hline & Jumlah & 100,0 & 100,0 & 100,0 & \\
\hline
\end{tabular}

salah satu bentuk keberlanjutan pengembangan sistem Padi Salibu oleh petani, yang memiliki pengaruh positif untuk keberlanjutan penerapan Padi Salibu di Sungai Tarab untuk periode tanam selanjutnya.

\section{Hubungan Karakteristik Petani terhadap Keberlanjutan Penerapan Teknologi Padi Salibu di Kabupaten Tanah Datar}

Karakteristik petani adalah ciri yang melekat pada diri petani, seperti umur, tingkat pendidikan formal, tingkat pedidikan nonformal, pengalaman berusaha tani, tingkat pendapatan, status dalam kelompok, status sosial, status kepemilikan lahan dan luas lahan. Hasil penelitian yang menjelaskan hubungan antara karakteristik petani terhadap keberlanjutan penerapan teknologi Padi Salibu dengan menggunakan analisis korelasi rank Spearman dapat dilihat pada Tabel 2.

Analisis korelasi rank Spearman pada Tabel 2 menunjukkan bahwa terdapat hubungan nyata pada taraf signifikan 0,05 antara indikator status petani responden dalam kelompok dengan penerapan Padi Salibu di setiap musim tanam dan pertambahan luas lahan. Hal ini mengindikasikan bahwa semakin tinggi status sosial seseorang di dalam kelompok maka semakin tinggi keinginannya dalam menerapkan dan memperluas lahan untuk pertanian Padi Salibu.Hal ini diperkuat oleh fakta yang ada di lapangan bahwa ketua kelompok lebih tinggi motivasinya dalam menerapkan teknologi Padi Salibu, bahkan terjadi peningkatan pemanfaatan lahan untuk teknologi Padi Salibu.

Tabel 2 juga menunjukkan bahwa terdapat hubungan nyata pada taraf signifikan 0,05 antara pengalaman berusaha tani, status dalam kelompok dan status sosial masyarakat terhadap penggunaan lahan dan pertambahan luas lahan di kecamatan Sungai Tarab. Hasil tersebut mengindikasikan bahwa semakin tinggi pengalaman petani dalam berusaha tani Padi Salibu maka semakin tinggi pula keinginannya untuk menggunakan lahan untuk pertanian Padi Salibu. Hal ini disebabkan bahwa petani tersebut sudah bisa merasakan keuntungan menggunakan teknologi Padi Salibu, yakni hemat tenaga, waktu dan biaya, karena tidak perlu mengeluarkan biaya pengolahan lahan, bibit dan pupuk. Lebih lanjut dapat dijelaskan bahwa status petani dalam kelompok dan status dalam lingkungan sosial berhubungan nyata dengan penggunaan lahan dan pertambahan luas lahan, artinya petani yang memiliki status sosial yang tinggi cenderung menggunakan lahan dan memperluas lahannya untuk ditanami Padi Salibu. Berdasarkan keadaan dilapangan petani yang berstatus sebagai ketua kelompok menjadi contoh bagi anggota 
Tabel 2. Koefisien Korelasi Rank Spearman antara Karakteristik Petani terhadap Keberlanjutan Penerapan Teknologi Padi Salibu

\begin{tabular}{|c|c|c|c|c|c|c|c|c|c|c|c|}
\hline \multirow{2}{*}{\multicolumn{2}{|c|}{$\begin{array}{l}\text { Karakteristik } \\
\text { Petani Padi } \\
\text { Salibu }\end{array}$}} & \multicolumn{2}{|c|}{$\begin{array}{l}\text { Penerapan Padi } \\
\text { Salibu setiap } \\
\text { musim tanam }\end{array}$} & \multicolumn{2}{|c|}{$\begin{array}{c}\text { Penggunaan } \\
\text { lahan }\end{array}$} & \multicolumn{2}{|c|}{$\begin{array}{c}\text { Pertambahan luas } \\
\text { lahan }\end{array}$} & \multicolumn{2}{|c|}{$\begin{array}{c}\text { Keberlanjutan } \\
\text { penerapan Padi } \\
\text { Salibu } \\
\end{array}$} & \multicolumn{2}{|c|}{$\begin{array}{l}\text { Pengembangan } \\
\text { Padi Salibu }\end{array}$} \\
\hline & & $\begin{array}{l}\text { Sungai } \\
\text { Tarab }\end{array}$ & Batipuh & $\begin{array}{l}\text { Sungai } \\
\text { Tarab }\end{array}$ & Batipuh & $\begin{array}{l}\text { Sungai } \\
\text { Tarab }\end{array}$ & Batipuh & $\begin{array}{l}\text { Sungai } \\
\text { Tarab }\end{array}$ & Batipuh & $\begin{array}{l}\text { Sungai } \\
\text { Tarab }\end{array}$ & Batipuh \\
\hline 1. & Umur & 0,016 & 0,124 & 0,000 & $-0,107$ & $-0,078$ & 0,072 & 0,069 & 0,016 & $-0,076$ & 0,131 \\
\hline 2. & $\begin{array}{l}\text { Tingkat } \\
\text { pendidikan } \\
\text { formal }\end{array}$ & 0,109 & 0,044 & 0,102 & $-0,093$ & 0,057 & 0,187 & 0,050 & $-0,060$ & 0,029 & $-0,013$ \\
\hline 3. & $\begin{array}{l}\text { Tingkat } \\
\text { pendidikan } \\
\text { nonformal }\end{array}$ & $-0,154$ & 0,085 & 0,154 & $-0,021$ & 0,132 & 103 & $-0,047$ & $-0,044$ & $-0,061$ & 0,043 \\
\hline 4. & $\begin{array}{l}\text { Pengalaman } \\
\text { berusaha } \\
\text { tani }\end{array}$ & $-0,159$ & 0,144 & $0,302^{*}$ & $-0,014$ & 0,244 & 092 & $-0,122$ & 0,102 & $-0,084$ & 0,099 \\
\hline 5. & $\begin{array}{l}\text { Tingkat } \\
\text { pendapatan }\end{array}$ & 0,157 & $-0,118$ & 0,072 & $-0,153$ & 0,121 & 0,184 & 0,090 & $-0,069$ & 0,268 & 0,081 \\
\hline 6. & $\begin{array}{l}\text { Status } \\
\text { dalam } \\
\text { kelompok }\end{array}$ & 0,174 & $0,364^{* *}$ & $0,383^{* *}$ & $-0,152$ & $0,402^{* *}$ & $0,280^{*}$ & 0,174 & $-0,058$ & 0,141 & $-0,171$ \\
\hline 7. & Status sosial & 0,279 & 0,200 & $0,358^{*}$ & $-0,106$ & 0,254 & 0,044 & 0,279 & $-0,011$ & 0,225 & 0,115 \\
\hline 8. & $\begin{array}{l}\text { Status lahan } \\
\text { usahatani }\end{array}$ & 0,012 & 0,200 & $-0,197$ &, 140 & $-0,213$ & $-0,007$ & 0,012 & $-0,013$ & 0,064 & $-0,241$ \\
\hline & Luas lahan & 0,148 & $-0,035$ & 0,061 & $-0,145$ & 0,109 & 0,247 & 0,092 & $-0,075$ & 0,247 & 0,141 \\
\hline
\end{tabular}

${ }^{* *}$.Correlation is significant at the 0.01 level (2-tailed) ${ }^{*}$. Correlation is significant at the 0.05 level (2-tailed)

lain, di mana ketua kelompok dapat melakukan panen 3 hingga 4 kali dengan menggunakan teknologi Padi Salibu, sehingga sangat menguntungkan dan dapat meningkatkan pendapatan petani.

Sebaliknya, Tabel 2 juga memperlihatkan bahwa tidak terdapat hubungan nyata pada taraf signifikan 0,05 antara kepemilikan lahan dan luas lahan dengan keberlanjutan penerapan teknologi Padi Salibu di kecamatan Sungai Tarab dan kecamatan Batipuh. Berdasarkan observasi di lapangan, luas lahan petani yang rata-rata berada pada kategori sempit $(0.15-0.76$ ha) tidak menyurutkan minat petani untuk menerapkan padi salibu. Terlebih lagi, lahan yang diusahakan sebagian besar merupakan milik sendiri. Petani di Sungai Tarab dan Batipuh umumnya ingin terus menerapkan Padi Salibu karena keuntungan yang didapatkan, sehingga tidak dipengaruhi oleh luas lahan dan status kepemilikan lahan.

Hasil tersebut mengindikasikan bahwa tidak selamanya karakteristik petani mempengaruhi keinginan petani untuk melanjutkan penerapan Padi Salibu pada lahan mereka. Menurut Lalla et al. (2012) bahwa karakteristik petani seperti umur, tingkat pendidikan, dan luas lahan tidak selamanya berhubungan dengan adopsi inovasi, karena pengalaman berusaha tani, status dalam kelompok serta status sosial di masyarakat turut mempengaruhi adopsi suatu inovasi. Demikian juga hasil penelitian Sadono et al (2014); Ajak dan Demiryurek (2017) bahwa karakteristik individu seperti umur, pengalaman berusaha tani, luas lahan, hingga tingkat pendapatan petani tidak berhubungan dan tidak berpengaruh terhadap pemberdayaan petani, akses informasi, atau bahkan diskriminasi sosial petani. Menegaskan hal tersebut, Emiria dan Purwandari (2014) serta Malta (2016) juga menyebutkan bahwa tidak terdapat hubungan antara pendidikan formal dan pengalaman berusaha tani dengan kemandirian petani dalam keberlanjutan penerapan usaha tani, terutama usaha tani padi dan padi organik. Namun hasil penelitian Senyolo et al. (2017) menyebutkan bahwa karakteristik petani seperti umur dan preferensi petani mempengaruhi mereka dalam menerapkan inovasi. Penelitian Ilori et al. (2017) juga menunjukkan bahwa umur dan pendidikan berpengaruh terhadap kemampuan petani dalam menerapkan inovasi. Hal ini dapat disimpulkan bahwa karakteristik petani, seperti umur, tingkat pendidikan formal, tingkat pendidikan non formal, 
tingkat pendapatan, status kepemilikan lahan dan luas lahan tidak selamanya berpengaruh terhadap penerapan inovasi teknologi Padi Salibu karena meskipun petani tidak memiliki pendidikan formal hingga SMA atau S1, tidak memiliki lahan pribadi dan hanya memiliki lahan sewa dengan luas yang sempit, petani tetap menerapkan teknologi Padi Salibu pada lahannya.

\section{Hubungan Karakteristik Inovasi Teknologi Padi Salibu terhadap Keberlanjutan Penerapan Teknologi Padi Salibu di Kabupaten Tanah Datar}

Menurut Rogers (2013), Meulen et al. (2016), dan Senyolo et al. (2017) karakteristik inovasi berpengaruh terhadap adopsi dan keberlanjutan suatu inovasi. Berbagai karakteristik inovasi tersebut dapat mendorong kecepatan adopsi inovasi, akan tetapi juga dapat menghambat adopsi inovasi (Warnaen et al. 2013). Hubungan antara karakteristik inovasi dengan keberlanjutan penerapan teknologi Padi Salibu pada penelitian ini ditunjukkan oleh Tabel 3.

Hasil analisa rank Spearman seperti yang terlihat pada Tabel 3, umumnya terdapat hubungan nyata pada taraf signifikan 0,05 antara karakteristik inovasi teknologi Padi Salibu dengan keberlanjutan teknologi Padi Salibu di kecamatan Sungai Tarab. Tabel 3 memperlihatkan bahwa indikator karakteristik inovasi yang terdiri atas keuntungan relatif, tingkat kesesuaian, tingkat kerumitan inovasi, tingkat kemudahan, dan tingkat keteramatan inovasi memiliki hubungan nyata terhadap indikator keberlanjutan yang terdiri atas keberlanjutan penerapan pada setiap musim tanam, keberlanjutan penggunaan lahan, hingga keberlanjutan terhadap pengembangan Padi Salibu di kecamatan Sungai Tarab. Akan tetapi, hanya terdapat beberapa indikator karakteristik inovasi teknologi Padi Salibu di kecamatan Batipuh yang berhubungan nyata pada taraf signifikan 0,05 terhadap keberlanjutan penerapan Padi Salibu, yaitu indikator tingkat ketumitan inovasi dan tingkat kemudahan. Hal ini mengindikasikan bahwa Kecamatan Sungai Tarab lebih cepat mengadopsi teknologi Padi Salibu dibandingkan Kecamatan Batipuh. Hal ini dikarenakan Kecamatan Sungai Tarab merupakan daerah yang sudah lama menerapkan Padi Salibu, artinya secara turun menurun sudah menerapkan Padi Salibu, dengan adanya teknologi Padi Salibu yang dibawa oleh BPTP makin memantapkan petani salibu di Kecamatan Sungai Tarab. Hubungan nyata antara karakteristik inovasi teknologi Padi Salibu dengan keberlanjutan penerapan Padi Salibu juga mengindikasikan bahwa semakin tinggi keuntungan relatif, tingkat kesesuaian, rendahnya tingkat kerumitan dan tingginya tingkat keteramatan inovasi teknologi Padi Salibu, maka semakin tinggi pula tingkat keberlanjutan penerapan teknologi Padi Salibu. Hasil penelitian menunjukkan bahwa teknologi Padi Salibu

Tabel 3. Koefisien Korelasi Rank Spearman antara Karakteristik Inovasi Teknologi Padi Salibu terhadap Keberlanjutan Penerapan Teknologi Padi Salibu

\begin{tabular}{|c|c|c|c|c|c|c|c|c|c|c|c|}
\hline & \multirow{2}{*}{$\begin{array}{l}\text { Karakteristik } \\
\text { Inovasi }\end{array}$} & \multicolumn{2}{|c|}{$\begin{array}{l}\text { Penerapan Padi } \\
\text { Salibu setiap } \\
\text { musim tanam }\end{array}$} & \multicolumn{2}{|c|}{$\begin{array}{l}\text { Penggunaan } \\
\text { lahan }\end{array}$} & \multicolumn{2}{|c|}{$\begin{array}{l}\text { Pertambahan } \\
\text { luas lahan }\end{array}$} & \multicolumn{2}{|c|}{$\begin{array}{c}\text { Keberlanjutan } \\
\text { penerapan Padi } \\
\text { Salibu }\end{array}$} & \multicolumn{2}{|c|}{$\begin{array}{c}\text { Pengembangan } \\
\text { Padi Salibu }\end{array}$} \\
\hline & & $\begin{array}{c}\text { Sungai } \\
\text { Tarab }\end{array}$ & Batipuh & $\begin{array}{l}\text { Sungai } \\
\text { Tarab }\end{array}$ & Batipuh & $\begin{array}{l}\text { Sungai } \\
\text { Tarab }\end{array}$ & Batipuh & $\begin{array}{c}\text { Sungai } \\
\text { Tarab }\end{array}$ & Batipuh & $\begin{array}{c}\text { Sungai } \\
\text { Tarab }\end{array}$ & Batipuh \\
\hline 1. & $\begin{array}{l}\text { Keuntungan } \\
\text { relatif }\end{array}$ & $0,294^{*}$ & $-0,013$ & $0,291^{*}$ & 0,052 & $0,316^{*}$ & $-0,101$ & 0,272 & $0-, 065$ & $0,301^{*}$ & $-0,103$ \\
\hline 2. & $\begin{array}{l}\text { Tingkat } \\
\text { Kesesuaian }\end{array}$ & $0,330^{*}$ & 0,126 & $0,288^{*}$ & 0,264 & $0,315^{*}$ & $0,345^{*}$ & $0,309^{*}$ & 0,049 & $0,348^{*}$ & $-0,115$ \\
\hline 3. & $\begin{array}{l}\text { Tingkat } \\
\text { Kerumitan } \\
\text { Inovasi }\end{array}$ & $0,488^{* *}$ & $0,324^{*}$ & 0,120 & $0,290^{*}$ & 0,059 & 0,237 & $0,351^{*}$ & 0,188 & $0,345^{*}$ & $-0,057$ \\
\hline 4. & $\begin{array}{l}\text { Tingkat } \\
\text { Kemudahan }\end{array}$ & $0,441^{* *}$ & 0,196 & $0,285^{*}$ & $0,320^{*}$ & 0,265 & 0,202 & $0,441^{* *}$ & $0,429^{* *}$ & $0,372^{* *}$ & 0,266 \\
\hline 5. & $\begin{array}{l}\text { Tingkat } \\
\text { Keteramatan } \\
\text { Inovasi } \\
\end{array}$ & $0,428^{* *}$ & 0,237 & $0,293^{*}$ & 0,011 & 0,273 & 0,172 & $0,454^{* *}$ & 0,066 & $0,382^{* *}$ & 0,013 \\
\hline
\end{tabular}

**) Correlation is significant at the 0,01 level (2-tailed)

*) Correlation is significant at the 0,05 level (2-tailed) 
tidak memiliki kerumitan yang tinggi, hal yang perlu diperhatikan dan menjadi esensial dalam penerapan teknologi Padi Salibu adalah waktu pemanenan 10 hari sebelum jatuh tempo dan jarak pemotongan $15 \mathrm{~cm}$ dari tanah. Dengan memperhatikan kedua hal ini akan sangat menentukan produktivitas Padi Salibu berikutnya.

Petani di kecamatan Sungai Tarab umumnya memahami bahwa teknologi Padi Salibu memiliki keuntungan dibandingkan padi konvensional, kesesuaian teknologi Padi Salibu mudah diadaptasi oleh petani dengan memperhatikan langkah teknis yang telah ada, tingkat kerumitan teknologi Padi Salibu juga rendah karena petani tidak perlu melakukan hal-hal yang sulit mulai dari proses panen pertama sampai panen berikutnya, teknologi Padi Salibu juga mudah untuk diterapkan serta inovasi tersebut bisa kita uji coba dengan keteramatan yang tinggi. Dengan demikian, petani di kecamatan Sungai Tarab memiliki keberlanjutan penerapan Padi Salibu, menggunakan lahannya kembali untuk ditanami Padi Salibu, bahkan lahannya sudah digunakan seluruhnya untuk Padi Salibu dan telah dikembangkan pula menjadi mina Padi Salibu.

Terdapat hubungan nyata pada tingkat kerumitan inovasi dan penerapan Padi Salibu setiap musim tanam, tingkat kerumitan dan kemudahan dengan penggunaan lahan, serta hubungan tingkatkemudahan dengan keberlanjutan penerapan Padi Salibu di Kecamatan Batipuh. Hal ini mengindikasikan bahwa rendahnya tingkat kerumitan dan tingginya tingkat kemudahan teknologi Padi Salibu menyebabkan adanya keberlanjutan penerapan teknologi Padi Salibu. Hasil observasi di lapangan menunjukkan bahwa petani di Kecamatan Batipuh tidak banyak yang melanjutkan teknologi Padi Salibu, hal ini dikarenakan aliran air irigasi yang tidak menentu pada musim kemarau turut menentukan motivasinya, walaupun dalam Padi Salibu tidak memerlukan banyak air, namun aliran air yang kontinyu sangat diperlukan. Sebaliknya, irigasi di kecamatan Sungai Tarab sangat lancar karena daerah Sungai Tarab berada di dataran tinggi, sehingga terdapat berbagai sumber mata air. Hal ini menyebabkan tidak terdapat masalah pengairan di kecamatan Sungai Tarab seperti halnya di kecamatan Batipuh.

Hasil penelitian di atas sejalan dengan temuan Edwina dan Maharani (2010), Sadikin (2013), Fachrista dan Sarwendah (2014), dan Sholahuddin et al. (2017) yang mengemukakan bahwa suatu inovasi yang memiliki keuntungan, mudah untuk diterapkan dan diamati, serta semakin sesuai dengan kebutuhan petani, maka akan semakin mudah pula petani mengadopsi suatu inovasi. Erdiman (2013) juga mengungkapkan bahwa kemudahan dalam teknologi Padi Salibu salah satunya adalah petani tidak perlu melakukan pembenihan dan pembajakan, yang mana sebagian besar biaya produksi tinggi pada kedua kegiatan tersebut.

\section{Hubungan Kearifan Lokal terhadap Keberlanjutan Penerapan Teknologi Padi Salibu di Kabupaten Tanah Datar}

Kearifan lokal masyarakat terbukti dapat membantu peningkatan produksi pertanian di Indonesia hingga mendorong kecepatan adopsi inovasi khususnya di bidang pertanian. Hal ini seperti hasil penelitian Putra et al. (2012) yang menyebutkan bahwa kearifan lokal membantu dalam adopsi inovasi pertanian di Kabupaten Aceh Besar, dan penelitian oleh Mulyadi et al. (2009) bahwa kearifan lokal di Papua Barat juga telah membantu penerapan inovasi di bidang pertanian. Penerapan teknologi Padi Salibu di Sumatera Barat merupakan salah satu bentuk kearifan lokal yang turut mendorong pembangunan pertanian. Padi Salibu yang berasal dari akronim kata Salinan Ibu dahulunya bertujuan untuk membantu janda dan orang miskin agar dapat mengambil sisa-sisa panen padi untuk kebutuhan mereka. Hal ini mengindikasikan bahwa terdapat nilainilai sosial dari kearifan lokal padi teknologi Padi Salibu berupa kebersamaan dan gotong royong. Analisa uji korelasi rank Sperman antara kearifan lokal dengan keberlanjutan penerapan Padi Salibu dapat dilihat pada Tabel 4.

Tabel 4 memperlihatkan bahwa terdapat hubungan nyata pada taraf signifikan 0,05 antara indikatorindikator kearifan lokal yang terdiri atas pengetahuan, keterampilan, dan proses sosial lokal dengan keberlanjutan penerapan teknologi Padi Salibu di kecamatan Sungai Tarab. Hanya indikator proses sosial yang memiliki hubungan nyata pada taraf signifikan 0,05 dengan keberlanjutan penerapan dan pengembangan Padi Salibu di kecamatan Batipuh. Hal ini mengindikasikan bahwa petani responden yang Padi Salibu di kecamatan Sungai Tarab lebih memiliki kesadaran untuk menjaga nilai-nilai dari nenek moyang terdahulu, sehingga adopsi Padi Salibu sebagai salah 
Tabel 4. Koefisien Korelasi Rank Spearman antara Kearifan Lokal dengan Keberlanjutan Penerapan Teknologi Padi Salibu

\begin{tabular}{|c|c|c|c|c|c|c|c|c|c|c|}
\hline \multirow{2}{*}{ Kearifan Lokal } & \multicolumn{2}{|c|}{$\begin{array}{l}\text { Penerapan Padi } \\
\text { Salibu setiap } \\
\text { musim tanam } \\
\end{array}$} & \multicolumn{2}{|c|}{$\begin{array}{l}\text { Penggunaan } \\
\text { lahan }\end{array}$} & \multicolumn{2}{|c|}{$\begin{array}{l}\text { Pertambahan } \\
\text { luas lahan }\end{array}$} & \multicolumn{2}{|c|}{$\begin{array}{c}\text { Keberlanjutan } \\
\text { penerapan Padi } \\
\text { Salibu } \\
\end{array}$} & \multicolumn{2}{|c|}{$\begin{array}{l}\text { Pengembangan } \\
\text { Padi Salibu }\end{array}$} \\
\hline & $\begin{array}{c}\text { Sungai } \\
\text { Tarab } \\
\end{array}$ & Batipuh & $\begin{array}{c}\text { Sungai } \\
\text { Tarab }\end{array}$ & Batipuh & $\begin{array}{l}\text { Sungai } \\
\text { Tarab }\end{array}$ & Batipuh & $\begin{array}{c}\text { Sungai } \\
\text { Tarab }\end{array}$ & Batipuh & $\begin{array}{c}\text { Sungai } \\
\text { Tarab }\end{array}$ & Batipuh \\
\hline $\begin{array}{l}\text { 1. Pengetahuan } \\
\text { lokal }\end{array}$ & $0,486^{* *}$ & 0,164 & 0,191 & 0,160 & 0,134 & 0,021 & $0,441^{* *}$ & 0,092 & $0,393^{* *}$ & $-0,121$ \\
\hline $\begin{array}{l}\text { 2. Keterampilan } \\
\text { lokal }\end{array}$ & $0,415^{* *}$ & 0,161 & $-0,033$ & 0,150 & $-0,097$ & 0,128 & $0,371^{* *}$ & 0,262 & $0,349^{*}$ & $-0,011$ \\
\hline $\begin{array}{l}\text { 3. Proses sosial } \\
\text { lokal }\end{array}$ & $0,503^{* *}$ & $0,319^{*}$ & 0,067 & 0,187 & $-0,005$ & $-0,028$ & $0,426^{* *}$ & $0,476^{* *}$ & $0,422^{* *}$ & $0,381^{* *}$ \\
\hline
\end{tabular}

**) Correlation is significant at the 0,01 level (2-tailed)

*) Correlation is significant at the 0,05 level (2-tailed)

satu teknologi yang dapat mendorong keberlanjutan pangan berbasis kearifan lokal menjadi semakin kuat, seperti halnya penelitian Suwartapradja (2010) yang menyebutkan bahwa kearifan lokal masyarakat dapat mendorong peningkatan produksi pertanian di Jawa Barat, seperti aplikasi padi jajar legowo. Disamping itu dengan adanya inovasi teknologi Padi Salibu yang digagas oleh BPTP Kabupaten Solok, membuat penerapan Padi Salibu lebih mudah dilakukan dengan memperhatikan waktu panen dan tinggi pemotongan. Hal tersebut mendorong keberlanjutan petani dalam menerapkan Padi Salibu di setiap musim tanamnya.

Tabel 4 juga memperlihatkan bahwa terdapat hubungan nyata pada taraf signifikan 0,05 antara proses sosial lokal dengan keberlanjutan penerapan teknologi Padi Salibu di Kecamatan Batipuh. Hal tersebut mengindikasikan bahwa proses sosial lokal baik berupa interaksi antar petani, interaksi dengan tokoh adat, maupun implikasi nilai-nilai sosial berupa gotong royong, nilai kebersamaan, dan saling membantu dapat meningkatkan keberlanjutan penerapan Padi Salibu oleh petani di Kecamatan Batipuh.

\section{Kesimpulan}

Tingkat keberlanjutan penerapan teknologi Padi Salibu di kecamatan Sungai Tarab dan kecamatan Batipuh sudah baik, di mana petani di kedua kecamatan telah menerapkan teknologi Padi Salibu pada setiap musim tanam. Hal ini didukung oleh karakteristik inovasi yang memiliki keuntungan, sesuai, tidak rumit, mudah diterapkan pada skala kecil, dan hasil yang dapat diamati; serta didukung oleh kearifan lokal masyarakat mengenai teknologi Padi Salibu yang terdiri atas pengetahuan, keterampilan, dan proses sosial.
Terdapat hubungan nyata antara karakteristik inovasi dan kearifan lokal dengan keberlanjutan penerapan teknologiPadi Salibu dikedua kecamatan. Keberlanjutan penerapan teknologi Padi Salibu di Kecamatan Sungai Tarab berhubungan dengan karakteristik inovasi yang terdiri atas keuntungan relatif, tingkat kesesuaian, tingkat kerumitan inovasi, tingkat kemudahan, dan tingkat keteramatan inovasi; dan kearifan lokal yang terdiri atas pengetahuan lokal, keterampilan lokal, dan proses sosial loka. Keberlanjutan penerapan teknologi Padi Salibu di Kecamatan Batipuh berhubungan dengan karakteristik inovasi yang terdiri atas tingkat kesesuaian, tingkat kerumitan inovasi, dan tingkat kemudahan; dan kearifan lokal yaitu proses sosial lokal.

\section{Daftar Pustaka}

Ajak, J. D. A.,dan Demiruyek, K. 2017. Agricultural Innovation System: Case of Cassava Producers in Kajo-Keji, South Sudan. American Journal of Agriculture and Forestry. 5(4): 94-101.

Aminatun, T., Widyastuti, S. H., dan Djuwanto. 2014. Pola Kearifan Masyarakat Lokal dalam Sistem Sawah Surjan untuk Konservasi Ekosistem Pertanian. Penelitian Humaniora. 19(1): 65-76.

Anggreany, S., Muljono, P., dan Sadono, D. 2016. Partisipasi Petani dalam Replanting Kelapa Sawit di Provinsi Jambi. Jurnal Penyuluhan. 12(1): 1-14.

[Balitbangtan] Balai Penelitian dan Pengembangan Pertanian. 2015. Panduan Teknologi Budidaya Padi Salibu. Jakarta: Kementerian Pertanian.

[Dirjen Tanaman Pangan] Direktorat Jenderal Tanaman Pangan. 2017. Pedoman Pelaksanaan Kegiatan Padi 2017. Jakarta (ID): Kementerian Pertanian.

Edwina, S., dan Maharani, T. 2010. Persepsi Petani 
terhadap Inovasi Teknologi Pengolahan Pakan Ternak di Kecamatan Kerinci Kanan Kabupaten Siak. Indonesian Journal of Agriculture Economis. 2, 170-183.

Emiria, F., dan Purwandari, H. 2014. Pengembangan Pertanian Organik di Kelompok Tani Madya, Desa Kebonagung, Kabupaten Bantul, Daerah Istimewa Yogyakarta. Jurnal Penyuluhan. 10(2): 113-122.

Erdiman.2013. Teknologi Salibu Meningkatkan Produktivitas Lahan (3-6 Ton/Ha/Tahun) dan Pendapatan Petani (Rp.15-25 Juta/Tahun). Balai Pengkajian Teknologi Pertanian Sumatera Barat. , Nieldanina, dan Misran. 2013. Inovasi Teknologi Salibu Meningkatkan Produktivitas Lahan, Mendukung Swasembada Pangan Berkelanjutan. Balai Pengkajian Teknologi Pertanian Sumatera Barat.

Fachrista, I. A., dan Sarwendah, M. 2014. Persepsi dan Tingkat Adopsi Petani Terhadap Inovasi Teknologi Pengelolaan Tanaman Terpadu Padi Sawah. Agriekonomika. 3(1): 1-10.

Herlinda, S., Dewi, R., Adam, T, Suwandi, dan Wijaya, A. 2015.Struktur komunitas laba-laba di ekosistem padi ratun: pengaruh aplikasi Beauveria bassiana (Balsamo). Jurnal Entomologi Indonesia.12(2): 9199.

Ilori, A. B., Lawal A. F., dan Oke S. 2017. Effect of Socio-Economics Characteristics, Production and Innovation Capabilities on the Performance of Palm Kernel Processing Firms in South-western Nigeria. IJERMT. 6(1): 88-95.

Lalla, H., Ali, M. S. S., dan Saadah. 2012. Adopsi Petani Padi Sawah Terhadap Sistem Tanam Jajar Legowo 2:1 di Kecamatan Polongbangkeng Utara, Kabupaten Takalar. J Sains \& Teknologi. 12(3): 225-264.

Malta. 2016. Faktor-faktor yang Berhubungan dengan Kemandirian Petani dalam Pengambilan Keputusan untuk Keberlanjutan Usahatani (Kasus: Petani di Desa Sukaharja - Kabupaten Bogor). Sosiohumaniora. 18(2): 118-124.

Meulen, H. V. D., Assseldonk, M. V., dan Ge ,L. 2016. Adoption of Innovation in European Agriculture. Europe.

Mulyadi, Sugihen, B. S., Asngari, P. S., dan Susanto, D. 2009. Kearifan Lokal dan Hambatan Inovasi Pertanian Suku Pedalaman Arfak di Kabupaten Manokwari Papua Barat. Jurnal Penyuluhan. 5(1): 9-14.
Putra, A. W. S., Hariadi, S.S., dan Harsoyo. 2012. Pengaruh Peran Penyuluh dan Kearifan Lokal terhadap Adopsi Inovasi Padi Sawah di Kecamatan Montasik Kabupaten Aceh Besar. KANAL. 1(1): 85-101.

Ritonga, E. S. 2015. Uji Adaptasi Galur - Galur Padi Ratun di Lahan Pasang Surut Kabupaten Pelalawan Provinsi Riau. Prosiding Seminar Nasional Lahan Suboptimal.

Rogers, E. 2003. Diffusion of Innovations Fifth Edition. New York (AS): The Free Pr.

Sadikin, I. 2013. Pengaruh Faktor Sosial Ekonomi Terhadap Adopsi PTT di Sentra Padi Jawa Barat. Agros. 15(1): 123-136.

Sadono, D., Sumardjo, Gani, D. S., dan Amanah, S. 2014. Farmer Empowerment in The Management of Rice Farming in Two Districts. Journal of Rural Indonesia. 2 (1): 105 - 126.

Senyolo, M. P., Long, T. B., Blok, V., dan Omta, O. 2017. How the characteristics of innovations impact their adoption: An exploration of climate-smart agricultural innovations in South Africa. Journal of Cleaner Production. 30: 1-16.

Sinaga, P. H., Trikoesoemaningtyas, Sopandie, D., dan Aswidinnoor, H. 2015. Daya Hasil dan Stabilitas Ratun Galur Padi pada Lahan Pasang Surut. Penelitian Pertanian Tanaman Pangan. 34(2): 97104.

Sholahuddin, Setyawan, A. A., dan Trisnawati, R. 2017. Pengaruh Karakteristik Inovasi terhadap Niat Mengadopsi Solopos Epaper. Prosiding Semnas Riset Manajemen \& Bisnis. 63-84.

Susilawati, dan Purwoko, B. S. 2012. Pengujian Varietas dan Dosis Pupuk untuk Meningkatkan Pertumbuhan dan Hasil Ratun-Padi di Sawah Pasang Surut. Jurnal Pengkajian dan Pengembangan Teknologi Pertanian. 15(1): 47-54.

Suwandi, Ammar, M., dan Irsan, C. 2012. Aplikasi Ekstrak Kompos Meningkatkan Hasil dan Menekan Penyakit Padi Sistem Ratun di Sawah Pasang Surut Kabupaten Banyuasin.Jurnal Lahan Suboptimal. 1(2): 116-122.

Suwartapradja, O. S. 2010. Pranata Sosial dalam Pertanian: Studi tentang Pengetahuan Lokal pada Masyarakat Petani di Jawa Barat. Sosiohumaniora.12(1): 86-98.

Warnaen, A., Cangara, H., dan Bulkis, S. 2013. FaktorFaktor yang Menghambat Inovasi pada Komunitas Petani dan Nelayan dalam Meningkatkan 
Jurnal Penyuluhan, Maret 2019 Vol. 15 No. 1

Kesejahteraan Masyarakat di Kabupaten Takalar.

KAREBA. 2(3): 241-249. 